\title{
The Encouragement of Reading Through Ownership of Books and Book Selection
}

Miss Stone is assistant director of libraries for public services, Southern Illinois, University.

A RECENT article ${ }^{1}$ has attested to the fact that students may not continue to be readers after leaving college, while another ${ }^{2}$ informs us that "College Students Do Read." In the latter article the query is made, "Does the library do anything to promote membership in book clubs and ownership of pocketbook editions?"3 For some time, one of our plans for making students permanent readers is to sell them books. It is our theory that if students become purchasers, reading is likely to be continued. Since Southern Illinois University is not situated in a metropolitan area, and there is only one small bookstore, we have added one copy of each important title in the inexpensive reprint series. These are for inspection purposes only, and as such are always on display. A poster near the collection advises the student to "Build Up Your Own Library of Good Books." After listing in I, 2, 3 order the steps necessary for the ordering of these titles, the placard further admonishes, "Browse as often as you like, but the books in this group may not be withdrawn from the library. They are here for display only." Books are shelved by series

1 Canfield, Cass, "To Promote Reading," Library Journal, 76:911-16, June $1,195 \mathrm{I}$.

2 Abraham, Willard, "College Students do Read," Library Journal, 76:677-79, 693, April 15, 1951.

3 Ibid., p.693. with prices prominently displayed, and there are at least two thousand titles in this openshelf collection. Order blanks are placed on a near by table. When the bibliographical information has been entered on the blank and checked by the Circulation Division, the orders are given to the University Bookstore (which serves only as a textbook rental store) and the items are ordered. Upon receipt the purchaser is notified by telephone. From the beginning orders have averaged at least one hundred per month.

The collection is not allowed to become static; each worth while title published in an inexpensive reprint series is added. Selections are chosen carefully by experienced, professional staff members. At periodic intervals an inventory is taken of the collection to determine how many and which titles are missing. These are then reordered. It is not too surprising to note that some few of the titles are repeatedly listed as "missing," but our loss has not been great.

The collection is publicized in the university weekly paper, and by displays of the material on bulletin boards. At the time of writing, an effective display informs the public, "You Can Own All of These for Five Dollars." Those currently exhibited are: Photography As a Hobby, by Fred B. Barton (Perma); You, Too, Can Be the Perfect Hostess, by Maureen Daly (Pocket); Handy World Atlas (Perma); Essentials of Arithmetic, by Henry Sticker 
(Perma); Better Speech for You, by Daniel P. Eginton (Perma); Best Loved Poems, edited by MacKenzie (Perma); The Merriam-Webster Pocket Dictionary (Pocket); The Pocket Cook Book, by Woody (Pocket); The Dictionary of First Aid, by Pomeranz (Pocket); Great Operas, by Simon and Veinus (Pocket); Handy Book of Indoor Games, by Mott-Smith (Perma); A Treasury of Folk Songs, by Kolb (Bantam); Old Masters, edited by Wechsler (Pocket); The Handbook for House Repairs, by Gelders (Perma); The Handybook of Useful Information, edited by Copeland (Perma); The Consumer's Guide to Better Buying, by Margolius (Signet).

A small typed notice informs the viewer of the exhibit, "Other titles are available for consultation in the reprint collection, which is shelved near the circulation desk. Copies of these and other books in the reprint collection may be ordered by filling out one of the mimeographed forms and leaving it with an attendant at the circulation desk."

The Great Books, Modern Library, Everyman's Library, Perma Books, Perma Giants, Pocket Books, Signet and Mentor Books, Penguin Books (both American and English), Bantam, Pelican, Rinehart Editions, Harper's Modern Classics, Halcyon House Books, Viking Portable Library, Collector's Editions, Reviewers' Selections are among the series displayed. This group will be expanded to greater length. As books become out-of-print they are removed from the collection. A careful check is made as to the length of time required before the purchasers receive their books. If the time required appears too great, an effort is made to obtain them more quickly. So useful have the reprint series been that the History Department has ordered various titles in quantity in order to meet the needs of the reserve collection. These are not cataloged, and are destroyed when their physical condition becomes poor.

Our other plans relate to the selection of books for the university libraries, a task which if properly done should encourage reading. All book selection for the university libraries is coordinated in the office of the assistant director of libraries for public services. Book budgets are allocated by the Library Committee with the advice of the director of libraries. Each departmental chairman designates one member of his department (which in many cases may be himself) to serve as library representative for the year. To this person is sent all information about new books, reprints, new series, books on microcards or microfilm which comes to the office of the assistant director. This includes advertising material such as the Tuesday Letters sent out by the Macmillan Company, the annotations of their new books published by Longmans Green and Company, the library cards received from various publishers, such as Wiley, McGraw-Hill, and others. Special attention is paid to those subject areas in which the library book collection is known to be weak and reasonably rapid growth has been made in building collections in several fields. Such material is accompanied by a mimeographed form, which is filled in with the name of the faculty member, asking him to complete orders which will be charged against the proper departmental library book fund.

Catalogs which list second-hand material receive special care. They are not permitted to lie in a basket awaiting attention but are dated and sent immediately to the department concerned. A letter, which accompanies all second-hand catalogs, contains an explanation of the need for prompt checking of catalogs so as to insure procurement of the materials. We receive a prompt response from all departments, as they realize we are quite unlikely to be able to secure material if the lists have been held 
for more than a week by faculty departments. All orders for second-hand books are ordered "rush." The Order Division is aided by the return of the catalog with the request for the material.

Two copies of Publishers' Weekly and Library Journal are subscribed to for the use of this office in clipping. The "Weekly Record" and "Books Appraised are carefully studied, and the name of the appropriate library representative is written in the margin beside the various books which the faculty members may be interested in adding to the university libraries. This bibliographical information and annotations are cut out and pasted on order cards and sent with a mimeographed notice to the various library representatives. The notice requests the signature of the person and the department, as well as a statement to the effect that the item will be charged to the department. Since all order cards are routed to the office of the assistant director of libraries for public services, it is soon obvious which departments are discriminating purchasers and which are less active and less interested in adding to the university collection.

Other periodicals checked regularly for library representatives include: Booklist, Literary Supplement to the London Times, Saturday Review, reviewing sections of Wilson Library Bulletin, Library Quarterly, and others. Books Abroad is routed each quarter to the chairman of the Department of Foreign Languages.

The chief of the Education Library checks new education and psychology periodicals, such as American Journal of Psychology, Education Index, Higher Education, School Life, and School and Society. Order cards are typed and sent to the library representatives in the education and psychology departments to encourage the building up of these collections.

In addition to periodicals checked for new publications many bibliographies are checked with the card catalog and those not included in this library are sent to the proper department for possible purchase. Typical lists include the Bibliography on Elementary Education published by the Association for Supervision and Curriculum Development, and the Harvard List of Books in Psychology.

Booklists from other libraries are looked over for titles which we may have missed.

Especial attention is paid throughout the year to lists of outstanding titles in various fields. These are regularly checked, and titles not yet ordered are called to the attention of the various library representatives. Typical lists include "Outstanding Educational Books of 1950 ," printed in the Journal of the National Education Association, "Educational Literature Review," which appears in each issue of School and Society, "The Year in Books," published in Time, "The Literary Summing-Up, a Personal Winnowing of 1950's Books," which appeared in the Saturday Review of Literature; "Among The Outstanding Books of 1950," from the New York Herald Tribune Book Review, and such lists as appeared in Books Abroad of "Des Douze Meilleurs (French) Romans du Demi-Siècle." These all serve as some measure of the collection, and indicate to an extent whether or not the work has been effective.

Many expressions of appreciation have come from the library representatives. Here is a typical comment from the department of business administration: "Your service in sending us these order suggestions is wonderful and I feel should be followed through." This one is from the library representative for the department of geography: "It is such fine materials which you unearth so abundantly that makes my work as the library representative for the Geography Department a real pleasure. I deeply appreciate all of the aid you have so generously given me because I certainly 
could not do my job as library representative without your valuable assistance. The Northwestern University Library list (a bibliography in the field of geology) you have just sent me is one of many examples of real service you are rendering to our departiment.

"May I take this opportunity to express my appreciation of another service you render to me and that is your policy of sending me information about all new publications you run across in my fields. Certainly I could not possibly keep track of all of them. I, for one, hope that you may continue this service too."

And from the Art Department: "Miss has asked me to express her thanks to you for sending her order cards for the books, "Navaho Weaving," and "Key to Weaving." She also suggested that you might keep up the good work. We have checked these two books for special order and intend to make good use of them."

The representative from journalism wrote, "Your manner of filling out these cards on new books is really helpful, and I appreciate the service."

Industrial Education wrote: "A most excellent selection. May I express my sincere thanks to the university library for the service. I think it is a good one."

Each library representative receives each month from the Order Division of the library a statement of funds spent, amount encumbered and amount available for expenditure. The university fiscal year extends from July I through June 30 , and on April I all unspent or unencumbered funds revert to the General Library Book Fund.

The General Fund is usually rather large, and is very flexible. If a new department is begun or special course offerings were not planned until after funds have been allocated, a portion of the General Fund is used for building up its collection.
Special items, too expensive for any one department to purchase are paid for from this fund, as are all reference materials, all books which would be used by several departments (and for which no single department would feel justified in expending its funds). Another function of the General Fund is in filling gaps in the collection. Replacements of worn out and missing books and recreational reading sections are purchased from this fund.

Recreational reading is selected in two ways. We make no especial point of purchasing best sellers, but we do wish to purchase the best fiction titles, both American and foreign. Therefore, we wait for the monthly issues of Book Review Digest, and carefully consider all fiction suitable for a university library.

Broadway plays are also purchased for recreational reading. These were selected from 1940 to date from the Book Review Digest. Current ones are found and suggested for order at the time the Publishers' Weekly, Library Journal, and other sources are checked.

Another plan by which we encourage reading is through three types of permanent exhibits, the material in each one being changed frequently. The chief of circulation selects from the new books added to the library those which in her opinion are of general interest. These are displayed on open shelves for two weeks in order that all may see them. These are not permitted to circulate for this period, but personal reserves are accepted and at the end of the period may be called for.

A special fiction shelf includes worthwhile novels not more than two or three years old. These circulate at once, but are returned to the shelf after they have been discharged. (The newer fiction titles are displayed, not because we believe that these are more worth-while than older standards or classics, but the older ones 
are better known and hence easier to find under author or title.) Students who would have little time to select titles from the card catalog choose a volume in passing.

The third permanent display is of Broadway plays, which is an unrelated project of the chief of the Education and Psycholsgy Library. She selects the titles to be purchased and maintains the display. This group of books also circulates at once, and books are marked "To be Returned to Drama Bookshelf."

The circulation of each of these types of material has more than tripled since these special displays have been used.

An exhibit committee plans and supervises the execution of displays on various bulletin boards scattered throughout the library building. These usually consist of book jackets on timely topics, and each bulletin board covers one specific subject. Call numbers are listed, and often inquiries for these titles come rapidly to the circulation desk. A few of the topics around which displays were centered during the past year were: A journalism display, exhibited at the time of the meeting of the Southern Illinois Editorial Association; Literary Awards of the Year; the State Department in the News; Korea; ECA; Gateway Amendment; Human Rights Day; United Nations Week; and I950 Legislation. For one or two bulletin boards, use is made of government documents and of pamphlet material which tends to keep this type of matter before the students and faculty members.

A selected list of new books added to the university libraries is mimeographed each month and sent to each department. Interested faculty members may receive a personal copy by asking that their name be added to the list. A questionnaire is sent to each faculty member at the beginning of each academic year asking:
"Is the Booklist helpful to you?

Do you wish to continue to receive it? Do you make use of the entire list?

Do you usually use only that section which lists books in your subject area?

Do you wish to receive only the section pertaining to your major field?

Might one copy posted in your department meet your need?

Would you prefer to have your own copy?

The results of the questionnaire determine who is to receive the Booklist.

An attempt has been made to build up and also to measure the book collection through the use of the excellent collection for Harvard undergraduates in the Lamont Library, recently selected by the Harvard faculty and library staff. ${ }^{4}$ Over 40,000 cards representing titles in the Lamont Library were checked against our holdings, and purchase of the 15,000 which were not in this library has begun and will proceed as funds become available. Possibly only about $10 \%$ of these 15,000 titles were acquired in 1950 , and were concentrated in the areas of geography, geology, guidance, special education, anthropology and philosophy.

We are taking advantage of the wisdom and knowledge of Harvard's combined faculty, which is in part embodied in the order cards for their Lamont Library.

Because we firmly believe that it so important that people be apprised of the issues before the world today, because we believe their convictions will be formed to a great extent by the material read, and because reading should be made as attractive as possible we give book selection and the encouragement of reading top priority in this University Library.

4 Williams, Edwin E., "The Selection of Books for Lamont," Harvard Library Bulletin, $3: 386-94$, Autumn 1949. 